\title{
Market Orientation, Product Innovation on Marketing Performance Rattan Industry in Cirebon Indonesia
}

\author{
Suparman ${ }^{1}$ Endang Ruswanti ${ }^{2}$ \\ Magister Management Esa Unggul University Jakarta
}

\begin{abstract}
Companies build strategy through market orientation and product innovation through the development or creation of new products, to provide optimum service, so that companies are able to create competitive advantage and improve marketing performance better.The research problem there are gaps between market orientation and product innovation to organizational performance. The purpose of this study was to determine the effect of market orientation, product innovation and competitive advantage to marketing performance. Respondents study of 170managers rattan industry in Cirebon, West Java through questionnaires. Methods of data analysis in this study using Structural Equation Modeling. The results showed that market orientation has a positive influence on competitive advantage. Product innovation together with increasing market orientation and the competitive advantage of research findings show there is a positive influence on the performance of competitive advantage of marketing and competitive advantage to mediate the effect of market orientation and product innovation on the performance of marketing
\end{abstract}

Keywords: market orientation, product innovation, competitive advantage, marketing performance.

\section{Pendahuluan}

Competition in the business world is unavoidable, companies are faced with various opportunities and threats both from outside and from within the country. Companies are required to understand what is happening in the market, what the consumer desires, and various changes in the business environment in order to compete with similar companies. Companies need to select and define the appropriate strategy to be able to create competitive advantage. Dimensions of market orientation need continuous innovation to offer additional services to customers. Gunarathne (2015) found the market orientation of social benefits added component orientation provides a new perspective on the theory of market orientation. A commonly used strategy firm market orientation and innovation (Narver and Slater, 1990). Salman (2015) describes the continuous innovation in the enterprise is the basic requirement for the creation of competitive advantage. Innovation is seen as a mechanism for companies to adapt to a dynamic environment.

Product innovation is one of the effects of competitive advantage by Han et al (1998). Li (2000) found there are significant competitive advantage with performance through sales volume, the rate of profit, market share, and return on investment. Competitive advantage has the strength to compete with other companies and products remain in demand so that customers competitive advantages have a positive influence on the increase marketing performance. Several studies have shown a strong correlation between market orientation and corporate performance (Matsuno et al., 2000), whereas the results of contradiction is found (Han et al., 1998; Jaworski and Kohli, 1993). The research found that the market orientation affect the performance of the organization (Bhuian, 1998; Deshpande et al., 1993; Harris and Ogboma, 2001; Jaworski and Kohli, 1993; Matsuno and Mentzer, 2000; Pitt et al., 1996; Selnes et al ., 1996).

Innovation related to the performance of the company, has been discovered by (Damanpour and Evan, 1984; Zahra, de Belardino, and Boxx, 1988) is different from the findings of Mavondo et al. (2005) product innovation does not significantly influence the effectiveness of marketing. While Darroch (2005) found no effect on the innovation performance of both financial performance and non-financial performance as market share and sales growth. Sales continue to occur and earnings continue to rise is not necessarily stable if not innovation and added value for consumers. Marketing performance drop due to marketing strategies are not appropriate. The research object rattan industry in Cirebon, West Java, Indonesia has the opportunity to be the biggest rattan producer in Asia and the world. Indonesia has a comparative advantage sufficient availability of raw materials, human resources, skills, investment growth climate. Market-oriented corporate strategy and product innovation are expected to compete in the global market agarmeningkatkan marketing performance.

\section{Literature Review}

Relations Market Orientation, Product Innovation, Competitive Advantage, Performance Marketing Narver and Slater (1990) define market orientation as an organizational culture that is most effective and efficient to create behaviors that can produce a best for the buyer and generate superior performance for the company. Finding a market orientation relationship with the marketing performance still give different results, 
but research market orientation and performance marketing is still interesting to do for the benefit of the strategy. Craven (1996) define market orientation as a strategic goal setting and building consumer-focused organization serving customers in line with expectations so it managed to win the competition. Day (1994) mentions market orientation reflects competence in understanding the customer. Gunarathne (2015) put forward a new theory $i$ add market orientation orientation components of social benefits, the theory has not been widely used researching the market orientation. Akimova (1999) found a market orientation has a positive influence on competitive advantage. Bharadwaj et al. (1993) states the corporate culture emphasizes a market orientation on strengthening competitive advantages in order to improve marketing performance. But research Pelham, (1997); Selnes et al, (1996); Deshpande et al. (2000) found that market orientation has no effect on the growth and market share.Based on literature research the growth and market share. Based on literature research hypothesis: H1: Allegedly there is the influence of market orientation on competitive advantage

Hurley and Hult (1998) defines the company's product innovation a mechanism to adapt in a dynamic environment, companies must be able to create new thinking, new ideas and offers innovative products as well as increased service in order to satisfy customers. Fontana (2011) defines the product innovation for the company to bring economic success, social success for consumers as well as the wider community. Han et al. (1998) suggested innovation is not only focused technical issues but related to the administrative aspects of the organization. The emergence of product innovation basically to meet the market demand, so that product innovation is one of the company's competitive advantage. Gatignon and Xuereb (1997) presents three innovative characteristics consist of product excellence, cost of products and the credibility of product innovation. Product innovation can fail for reasons not offer unique designs according customer wants and needs. Product innovation can provide added value compared to similar products in order to make the company has an advantage over a competitor. Lukas and Ferrell (2000) describes the components of product innovation comprises (i) expansion of its line that the product produced by the company are not really new but relatively new to a market (ii) new product is a new product for the company but not new to the market (iii) completely new product is a new product that includes both the company and the market.

Droge and Vickery (1994) found a product innovation can be used as a source of competitive advantage.Companies that are able to design products according to customer wishes to be able to survive in the middle. Bharadwaj et al. (1993) found the company's ability to innovate on the product to keep in accordance with the wishes and needs of customers. Innovation increasingly has significance not only as a tool to maintain the viability of the company but rather a competitive advantage. Kurtinaitiene (2005); Lawton and Parasuraman (1980) stated there is no influence marketing concept to product innovation. Competitive advantage is a strong association between corporate excellence and effectiveness of the organization in adapting to environmental changes (South, 1981). Bharadwaj et al. (1993) suggested that competitive advantage requires that companies have the skills and resources worth more and different from the competitors, their products are not easily imitated and not easily replaced. Slater and Narver (1990) describes the results of the implementation of corporate strategies between consumer satisfaction, the success of new products, increased sales and profitability. Performance marketing is a common construct used to measure the impact of the company's strategy.However, the issue of performance measurement is an issue and the classic debate because as a construct, multidimensional marketing performance included a variety of objectives and types of organizations. Performance marketing is a common factor used to measure the impact of the company's strategy is always geared for performance marketing through sales volume, customer growth and rate of growth in sales and financial performance (Ferdinand, 2000). Research conducted by $\mathrm{Li}$ (2000) found a positive effect of competitive advantage with performance as measured by sales volume, the rate of profit, market share, and return on investment. Competitive advantage can be obtained from the company's ability to process and utilize resources and its equity. Companies are able to create competitive advantage will have the strength to compete with other companies for products remain attractive to customers so that competitive advantage to have a positive influence on the increase marketing performance. Wang et al. (2011) and Li et al. (2006) found there are significant competitive advantage and performance as measured in sales volume, the rate of profit, market share, and return on investment. Jap (2001) states the competitive advantage can be met if customers obtain product differences with competitors and market orientation of the company.Ferdinand (2000) states that marketing performance is a factor that is often used to measure the impact of the strategy applied by the company. The company's strategy has always aimed to produce marketing performance and financial performance. Based on the results of the research hypothesis:

$\mathrm{H} 2$ : Allegedly there are significant product innovation to competitive advantage

H3:Allegedly there are significant competitive advantage to marketing performance. 


\section{Research Methods}

Exogenous variable market orientation, product innovation and marketing performance endogenous variables, mediating variables competitive advantage. Indicators are measured variables to test the validity and reliability testing. Test the validity of using confirmatory factor analysis to see the value of Kaiser-Meyer-Olkin Measure of Sampling (KMO) and Measures of Sampling Adequacy (MSA). Value is achieved must be greater than 0.5 means that the factor analysis as appropriate, and the research can continue. Scale all variables produce valid values. Test reliability Cronbach alpha values greater than> 0.6 , which means a reliable indicator of the variables reliable as a means of collecting research data.The next phase, our data if using Structural Equation Modeling analysis method explain the relevance of variables in a complex and the effects of direct and indirect variable against another (Gozhali and Fuad, 2008; Hair et al., 1995).

Indicators used to measure the construct of market orientation adopt Narver and Slater (1990); Gatignon and Xuereb (1997); Gray et al. (1998); Han et al. (1998); Lukas and Ferrell (2000) and Gunarathne (2015) through customer orientation: the willingness of companies to understand the pelangganya, competitor orientation: the willingness of companies to monitor competitors, coordination between functions: the company's efforts to coordinate marketing activities between the functions within the organization, a fast response to changes in the competitive environment and to anticipate any change in its strategy, the orientation of social benefits: corporate responsibility towards the environment. Indicators used to measure the construct of product innovation refers to the study of Han et al. (1998); Gatignon and Xuereb (1997); Lukas and Ferrell (2000) is a line extension: extension products, counterfeit products: products of the same kind in the market, new products: new products for the company and the market.

Indicators used to measure the construct of competitive advantage refers to the study Bharadwaj et al. (1993) and Song and Parry (1997) is a unique product: the uniqueness of the company's products that differentiate it from competitors' products or general products in the market, product quality: quality of the product that had been created by the company, competitive price: the company's ability to produce products with prices that can compete in the market.Indicators used to measure the construct of marketing performance refers to the study Voss and Voss (2000). Performance marketing is a factor that is often used to measure the impact of the strategies the company is viewed from the aspect of marketing. Some of the indicators used to measure marketing performance product sales amount achieved by the company; Customer growth: customer growth rates achieved by the company; revenue growth: the magnitude of successful product sales profit obtained by the company.

Operational variables are measured with a five-point Likert scale where 1 indicates strongly disagree and 5 indicating strongly agree with a number of variables observed a number of 58 questions and consider the appropriate sample size for SEM between 100 to 200 (Hair et al. 1995; Ruswanti 2015), then the questionnaire in the study a number of 170 respondents.Gunarathne (2015) to measure market orientation adopted by the four dimensions of customer orientation, competitor orientation, coordination between fungi and orientation of social benefits. Through the pretest showed customer orientation, competitor orientation, coordination between function and orientation of social benefits declared invalid by the loading factor of $>0.5$ and overall reliability value $\alpha=0735$. Furthermore, based on Lukas and Ferrell (2000) to measure the variables of product innovation with the indicator line extension, counterfeit products, and new products are declared valid by the loading factor $>0.5$ on the reliability $\alpha=0621$. Competitive advantage by Bharadwaj et al. (1993) with indicator uniqueness of the product, product quality and competitive price is valid loading factor $>0.5$ with reliability value $\alpha=0949$. Pretest measurement of marketing performance variables by Ferdinand (2000) indicator is the volume of sales, customer growth and revenue growth is declared invalid by the loading factor $>0.5$ and the reliability value $\alpha=$ 0821.

\section{Reults Analysis And Discussion}

Hair et al. (1995) mentions that the observation variable decent used as an indicator to construct or latent variable must have a load factor greater than 0.5 so that the model used to have a good match, besides the value-t load factor must be greater than the critical value (>1.96). Bagozi and Yi (1988) good reliability requirement is to have the construct reliability $>0.6$ and variance extracted $>0.5$. Therefore, there are four variables with the value of reliability and variance extracted construct that meet the minimum requirements, then the value of the overall suitability model (goodness of fit) were 0.96 and RMSEA is 0 where it shows the compatibility of sufficient overall (good fit). 


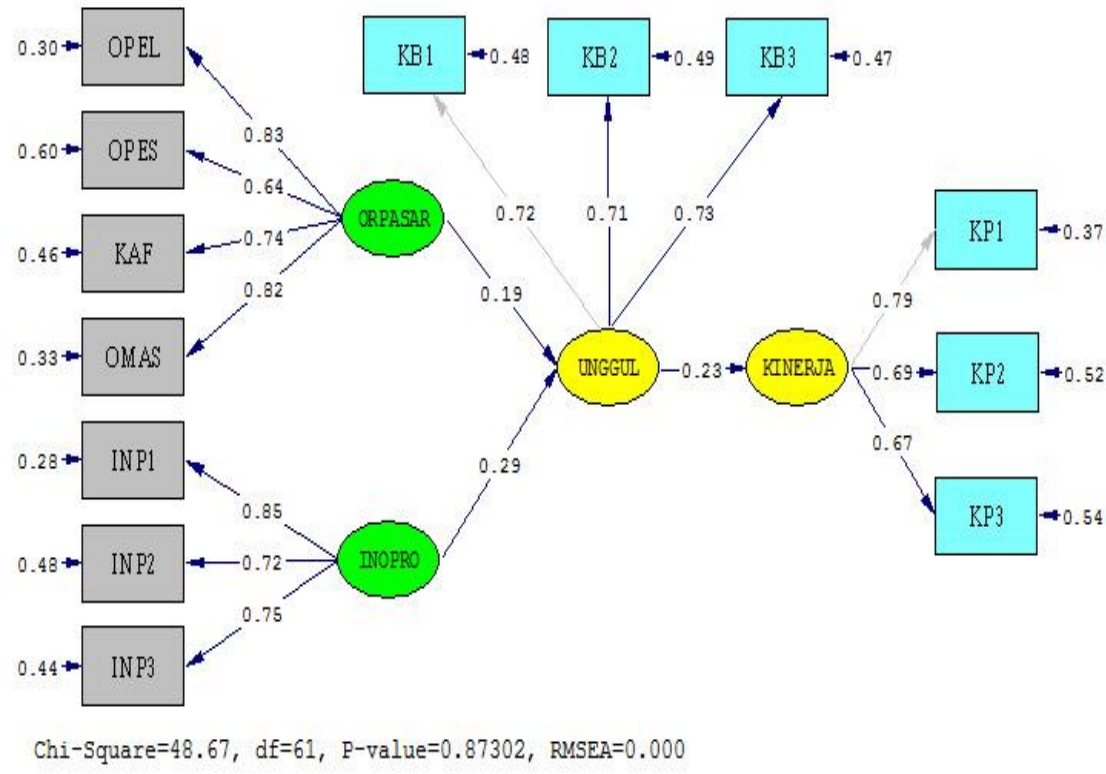

Figure2. Path Diagram Model

Figure 1 shows Orpasar $=$ market orientation, Inopro $=$ product inovation, Unggul $=$ competitive performance, Kinerja $=$ marketing performance. The output path diagram in which the first hypothesis test results, it was found that the analysis results support the hypothesis that there is an influence on the market orientation of the company's competitive advantage of 2.06 over 1.96. Shows that the competitive advantage of companies affected by the orientation of the market operated by the company. The higher the market orientation that runs the company will influence and improve the company's competitiveness on the market. The results of this study reinforce previous research conducted by Akimova (1999) proved that market orientation has a positive influence on competitive advantage. Companies that implement market orientation has advantages in terms of customer knowledge and the excess can be used as a source for creating products that fit customer needs and requirements. The orientation of the social benefits of this research proves it as proposed by Gunarathne (2015) which gives a new perspective on the theory of market orientation supports previous theories about market orientation there are only three components: customer orientation, competitor orientation and coordination between functions (Narver and Slater, 1990).

In the first hypothesis analysis concluded that market-oriented company constantly efficiency and always create more value for its customers that is expected to provide long-term profitability of the company. For the company should make the customer as the totality of the company. Focus on the customer is the starting point of view of quality for customer satisfaction while observing existing competitors and are also supported by cross-functional coordination of synergistic companies. In addition the company is also required to conduct social activities to customers or the surrounding community so that consumers will be loyal to the company itself later.Results of testing the hypothesis 2 that the influence of product innovation affect the competitive advantage by 2.95 . This shows that competitive advantage is influenced by the level of product innovation of the company.The higher the innovation of products that will further enhance the product competitive advantage against other companies or the market. The results of this study support Droge and Vickery (1994) that the product innovation can be used as a source of competitive advantage. Companies that are able to design products according to customer wishes is able to survive in the competitive because the products remain in demand of customers.

The same research results presented by Bharadwaj et al. (1993) that the company's ability to continue to innovate product will keep the product remains in accordance with the wishes and needs of customers. Product innovation together with market orientation can increase competitive advantage, it is in line with research Salman (2015) that innovation and creativity to market-oriented and sustainable is a basic requirement in turn leads to the creation of competitive advantage.Results of testing the third hypothesis was found that the analysis results support the hypothesis 3 that there is influence between the competitive advantage of 2.28 to performance marketing. This suggests that marketing performance is influenced by the competitive advantage. High competitive advantage will improve the performance of companies with good marketing, but on the contrary if the company's competitive advantage is low, the company will be difficult to improve marketing performance because of competition with competitors' products. The results of this study has established and according to research $\mathrm{Li} \mathrm{(2000)}$ there is a positive influence between competitive advantage with performance as 
measured by sales volume, the rate of profit, market share, and return on investment. Competitive advantage can be obtained from the company's ability to process and utilize resources and its equity. Companies are able to create competitive advantage will have the strength to compete with other companies because their products will remain in demand by customers so that competitive advantage to have a positive influence on the company's marketing performance improvement.

\section{Managerial Implication}

Based on our research, the analysis must be more market-oriented companies should consider several things: first, always thinking from the target market is not prefixed with existing products and new thinking to whom the product. The target market really should be studied in advance to reduce the risk of errors. The second aspect to consider is doing improvement to the product concept if needed to meet the desired specifications of consumers based on the results of the survey. The third aspect to consider is changing the attitude of top management and corporate culture of market and product orientation to a fourth aspect benchmarking continuously to the product and marketing performance. To find out how to deal with market competition, based on research results we obtained some conclusions as a step to win the market such as: observe the market and identify the company's competitors, create different products, highlight the advantages of the company's products, learn the strengths and weaknesses of competitors, offering competitive prices and then make a show or event to promote the company's products. The existence of coordination between company divisions function is very important in building a business, even to say whether or not a business developed strongly influenced by coordination that exist in it.

The stronger coordination to support a business, then the greater the chances of success are owned by the business and vice versa, when the team in it is not strong and working on their own, we can be sure that business cannot survive longer face the competitive world of business has always increasing every day. Despite building a strong coordination is an important step in building a business, but to create it in the middle of the work environment is not an easy task because it unites nature and character of every individual is different towards a common goal requires power, strategy and a long time. This makes the company leaders and managers must often hold special activities for their employees.Strategic orientation of social benefits has been linked in the creation of the brand image of the company itself. The public will be aware of and happy to buy products from companies that friendly and concerned with the social environment. So, when consumers see a company socially injury, they will not be interested in buying the products of the company. Not surprisingly, this current marketing strategy will be more successful if the businesses marketing strategy multiply horizontally (from individual to individual). For example, just by creating a web site to interact with customers, organize social movements to help others, and to plan activities caring environment to preserve our beloved earth. While vertical ways such as using one-way communication methods become less effective now, because now consumers are more critical in addressing any offers from market participants.

Innovation is necessary to minimize the decline. There are several important things relating to innovation in the face of business competition. Here we will explain about the importance of innovation in running the business. The first thing many people believe that innovation can be done at any time is wrong when the innovation must be done when the business starts to decline. Innovation must be done gradually, without forgetting the peculiarities of the business that we run. Both lowered idealism and receive advice, the third still anticipate the market is already saturated, then four remain vigilant if all current data about innovation plans that we have done is collected, it is better to do re-survey of the opinions of those directly related to our business, namely consumer. Do some surveys and monitoring of existing products to consumer with a record of all complaints and their opinion, then finally eliminate less unnecessary if all planned innovations we have noted and collected.Double check back on what you need and less necessary. It's necessary so that we can focus on the innovations of quality. How a company can achieve competitive success is to avoid competition with the protected domestic market or regulated, as the regulations may restrict competition through pricing and restrictions on the product, but it is temporary. Competitive strategy next that can be used is by providing a range of products, facilities and atmosphere that is more complete and attractively designed in such a way, as for social, cultural, economic and site selection also need to be considered, so as to compete with competitors that are superior to the company's competitive advantage will be able to improve the performance marketing company for the better. A company if it wants to survive on a minimum of a competitive business, the company must have more value. This value is not only measured in monetary lower prices, but also quality, service, support, and so, in accordance with the basic principles of marketing-oriented to its customers. So the basis of long-term success of a company's business is a sustainable competitive advantage that occurs when a business is able to provide a superior value to its customers consistently. We believe that sales growth is an effort to increase sales volume so that it will increase the profits of companies which in turn will support the company in business development. If the company has increased sales volume will increase profits and expand the company's assets. Companies can grow in a time long enough to produce a normal profit economically. Conversely, if the 
company has decreased, for example, a decrease in production, decline in profits, the decline of other resources such as difficulties in obtaining working capital, difficulties in obtaining raw materials, difficulties in obtaining inputs for already saturated market, reduced customer. All that will have an impact on the sales decline at the same time corporate profits. Evaluation control of marketing include some things that operational control or the annual plan, namely by assessing the performance of the ongoing with annual plans that had been made earlier and take corrective action where necessary in order to ensure that the company has reached the level of sales, profit and other targets that have been set the annual plan of the company, then control is to measure the profitability of the actual profitability by product, customer groups, distribution channels, and the amount of the booking. Last is the control strategy is to ascertain whether a strategy or plan that has been drawn up quite effectively with market conditions at a given time.

\section{Conclusion}

The results can be concluded from our research that the first is a market orientation affects the competitive advantage (H1 accepted). Factors that support the market orientation affect competitive advantage is customer orientation, competitor orientation, coordination between function and orientation of social benefits. Then the next is a product innovation affects the competitive advantage ( $\mathrm{H} 2$ accepted). Product innovation is one of the factors that can affect competitive advantage therefore the company to survive and excel in the market is expected to perform well its product innovation strategy. The third conclusion is affecting the competitive advantage of marketing performance. Company a competitive advantage that will increase the performance marketing (H3 accepted). Excelling in the competitiveness of the company cannot be separated from the strategy that has been implemented by the company, especially in this study refers to the strategy of market orientation and innovation product to create better marketing performance.

\section{Research Limitations And Suggestions}

Research is focused on industrial enterprises rattan or Business to Business between companies rattan where a company represented as a unit of research analysis and as a respondent managers medium-sized enterprises engaged in the rattan industry, using a questionnaire as a measuring tool for the purposes of saving time and energy, then the sample size should be expanded to rattan-producing areas in Indonesia. In addition, this study takes the research object in the city of Cirebon, West Java so that the conclusions obtained in this study is certainly not possible to be a generally accepted conclusions when applied to other objects outside the object of this study.In this connection it is possible if the research is done by entering other industries other than cane industry will be obtained different results. Related to answer the question about how to create a competitive advantage to improve marketing performance, we only focus on two factors, namely market orientation and product innovation. It is not impossible that there are actually other factors that may affect competitive advantage. Need to develop a market orientation in their policy in order to increase marketing will have a positive impact on competitive advantage. Product innovation should also be able to provide space to increase the company's competitiveness against competitors. We recommend that examined this issue by adding the influence of other factors that influence the competitive advantage. One factor that can be added is the distribution channels used. As a company that produces goods, the role of distribution channels is crucial for the company's success in selling their products. The existence of these studies are expected to be known whether the distribution channel can indeed be used as one source of the company to achieve competitive advantage.

\section{Bibliography}

[1]. Akimova, Irina. (1999). Development of Marke of Orientation and Competitiveness of Ukrainian Firm. European Journal of Marketing.

[2]. Bharadwaj, Sundar G., P.R. Varadarajan., \& Jihn Fahy. (1993). Sustainable Competitive Advantage in Service Industries: A Conceptual Model and Researh Proposisition. Journal of Marketing, 83-99.

[3]. Bhuian, S.N. (1998). An Empirical Examination of Market Orientation In Saudi Arabian Manufacturing Companies. Journal of Business Research.

[4]. Craven, David W. (1996). Pemasaran Strategis (Terjemahan). Jilid 1, Jakarta: Erlangga.

[5]. Damanpour, F. \& Evan, W.M. (1984). Organizational innovation and performance: the problem of organizational lag. Administrative Science Quarterly.

[6]. Darroch, Jenny. (2005). Knowledge Management, Innovation and Firm Performance. Journal of Knowledge Management.

[7]. Day, G. S. (1994). The Capabilities of Market-Driven Organizations. Journal of Marketing.

[8]. Droge, Cornelia., \& Shownee Vikery. (1994). Source and Outcames of Competitive Advantage: An Explanatory Study in The Furniture Industry. Decision Sciences.

[9]. Ferdinand, A. (2000). Manajemen Pemasaran: Sebuah Pendekatan Strategik. Research Paper Serie. Program Magister Manajemen Universitas Diponegoro.

[10]. Fontana, Avanti. (2011). Innovate We Can. Bekasi: Cipta Inovasi Sejahtera.

[11]. Gatignon, Hubert., \& Jean Marc Xuereb. (2015). Strategic Orientation of The Firm and New Product Performance. Journal of Marketing Research.

[12]. Ghozali, Imam., \& Fuad. (2008). Structural Equation Modeling: Teori, Konsep dan Aplikasi Dengan Program Lisrel 8.0. Semarang: Badan Penerbit UNDIP 
[13]. Ghosh, B. C., H.P. Schoch, D.B. Taylor, W. W. Kwan, \& T.S. Kim. (1994). Top Performing Organization of Australia, New Zeland and Singapore: Comparative Study of Their Marketing Effectiveness. Marketing Intelegence And Planning.

[14]. Greenley, G.E. (1995). Market Orientation and Company Performance: Empirical Evidence from UK Companies. British Journal of Management.

[15]. Gray, B., Matear, S., Boshoff, C. \& Matheson, P. (1998). Developing a better measure of market orientation. Journal of European.

[16]. Gunarathne, Umesh. (2015). Measurement Model of the Market Orientation: New Theoretical Framework NEWMKTOR Model. International Journal of Management and Commerce Innovations.

[17]. Hair, J. F., Anderson, R. E., Tatham, R. L., \& Black W. C. (1995). Multivariate. data analysis with readings (4 ${ }^{\text {th }}$ ed.). USA: Prentice Hall International Inc.

[18]. Han, Jin K., Narnwoon Kim., \& Rajenbdra K. Srivastava (1998). Market Orientation an Organization Performance: Is Innovation Missing Link. Journal of Marketing.

[19]. Harris, L.C \& Ogbonna, E. (2001). Strategic Human Resource Management, Market Orientation, and Organizational Performance. Journal of Business Research.

[20]. Hurley, R., \& Hult, T. (1998). Innovation Market Orientation and Organizational Learning: An Integration and Empirical Examination. Journal of Marketing.

[21]. Jap, S.D. (2001). Perspectives on Joint Competitive Advantages in Buyer-Supplier Relationships. International Journal of Research in Marketing.

[22]. Jaworski, B.J., \& Kohli, A.K. (1993). Market Orientation: Antecedents and Consequences. Journal of Marketing.

[23]. Lawton, Leigh \& A. Parasuraman. (1980). The Impact of the Marketing Concept on New Product Planning. Journal of Marketing.

[24]. Li, Ling X. (2000). An Analysis of Sources of Competitiveness and Performance of Chinese Manufacturer. International Journal of Operation and Production Management.

[25]. Li Suhong., Bhanu Ragu-Nathan., T.S. Ragu-Nathan., \& S. Subba Rao. (2006). The impact of supply chain management practices on competitive advantage and organizational performance. International Journal of Management Science.

[26]. Lukas, Bryan A., \& O.C. Ferrel (2000). Effect of Market Orientation on Product Inovation. Journal of The Academy Marketing Science.

[27]. Matsuno, K. \& Mentzer, J.T (2000). The Effects of Strategy Type on The Market Orientattion Performance Relationship. Journal of Marketing.

[28]. Mavondo, F.T., Chimhanzi, J., \& Stewart, J. (2005). Leaning Orientation and Market Orientation: Relationship with Innovation, Human Resources Practice and Performance. European Journal of Marketing.

[29]. Narver, J.C., \& Slater, S. F.(1990). Effect of Market Orientation on Business Profitability. Journal of Marketing.

[30]. Pelham, Alfred M. (1997). Mediating Influensure on The Relationship, Between Market Orientation and Profability in Small Industry Firm. Journal of Marketing Teory and Practice.

[31]. Pitt,L.,Caruana,A. \& Berthon, P. (1996). Market Orientation And Business Performance: Some European Evidence. International Marketing Review.

[32]. Ruswanti, Endang. (2015). Panduan Penulisan Laporan Ilmiah: Atensi, Kredibilitas Perusahaan, Iklan Dua Sisi Terhadap Niat Beli Jasa Penerbangan Elang Air. Yogyakarta: CV. Andi Offset.

[33]. Salman, Abbas S. (2015). The Effect of Market Orientation on Product Innovation. Journalof Business and Management.

[34]. Selnes, F., Jaworski, \& B.J Kohli, A.K. (1996) Market Orientation in United States And Scadinavias Companies: A Cross Cultural Study. Scandinavian Management Journal.

[35]. Slater, S. F., \& Narver, J. C. (1994). Does Competitive Environtment Moderrate the Market Orientation Performance Relationship?. Jornal of Marketing.

[36]. Song, X. Michael., \& Parry M.E. (1997). The Determinants of Japanese New Product Successes. Journal of Marketing Research

[37]. South, Stephen E. (1981). Competitive Advantage: The Cornerstone of Strategic Thinking. Journal of Business Strategy.

[38]. Speed, R., \& Smith. (1993). Customers, Strategy And Performance. International Journal of Bank Marketing.

[39]. Voss, G.B., \& Voss Z.G. (2000). Strategic Orientation and Firm Performance in an Artistic Environment. Journal of Marketing.

[40]. Wang, Guangping \& C. Fred Miao. (2011). Effects of Sales Force Market Orientation on Creativity, Innovation Implementation, and Sales Performance. Journal of Business Research.

[41]. Zahra, Shaker A., de Belardino, Stephanie., \& Boxx, W. Randy. (1988). Organizational Innovation: Its Correlates and its Implications for Financial Performance. International Journal of Management. 